\title{
Influence of Current Collector and Cathode Area Discrepancy on Performance Evaluation of Solid Oxide Fuel Cell with Thin-Film-Processed Cathode
}

\author{
Ji-Won Son ${ }^{1 .}$ and Hue-Sup Song ${ }^{2}$ \\ 1 High-Temperature Energy Materials Research Center, Korea Institute of Science and Technology, Seoul, South Korea, 136-791 \\ 2 Division of Advanced Materials Engineering, Kongiu National University, Kongju, South Korea, 330-717 \\ \# Corresponding Author / E-mail: jwson@kist.re.kr, TEL: +82-2-958-5530, FAX: +82-2-958-5529
}

KEYWORDS : Solid oxide fuel cell, Current collection area, Cathode area, Cell performance evaluation error

\begin{abstract}
The influence of the area difference between the current collector and the thin-film-processed cathode on the performance evaluation of the solid oxide fuel cell (SOFC) is investigated. Two $2 \mathrm{~cm}$ by $2 \mathrm{~cm}$ anode supported SOFCs with a $1 \mathrm{~cm}$ by $1 \mathrm{~cm}$ cathode (Cell-1.0) and a $1.5 \mathrm{~cm}$ by $1.5 \mathrm{~cm}$ cathode (Cell-2.25) are fabricated and the performances are measured in a button cell test set-up with a cathode current collection area of $1 \mathrm{~cm}$ by $1 \mathrm{~cm}$. Significantly different cell power outputs are measured. The total power output of the Cell-2.25 is 1.35 1.68 times to that of the Cell-1.0. The discrepancy is considered to originate from two major reasons: 1. limited lateral conduction and 2. thin thickness of the cathode. The cell performance can be overestimated when the smaller area is chosen, or underestimated when the larger area is chosen as the active area between the current collection area and the cathode area. The present study identifies another important factor to be considered to exactly assess the performance of the SOFC implementing thin-film-processed electrode.
\end{abstract}

Manuscript received: July 20, 2014 / Revised: August 17, 2014 / Accepted: August 23, 2014

\section{Introduction}

A Solid oxide fuel cell (SOFC) a fuel cell that is made of solid oxide (ceramic) materials and operates at a high temperature range $\left(\geq 700^{\circ} \mathrm{C}\right.$ in general). Owing to the high-temperature operation, an SOFC can easily use hydrocarbons as fuels, and among the technologies able to convert hydrocarbon-based fuels, the SOFC has the highest efficiency. ${ }^{1}$ In the lab scale, the performance evaluation the SOFC single cell usually implements button cell test set-ups. Single cells with lateral dimensions $\sim$ cm scale are subject to a dual chamber (separated air and fuel sides) test set-up with current collecting parts at each electrode side., ${ }^{2,3} \mathrm{~A}$ schematic of a button cell test set-up is presented in Fig. 1.

For thick, powder-processed conventional electrodes, these set-ups mostly assess the cell performance well. Recently, thin-film-processed cathodes with nano-size grains are actively studied for higher electrode activity originating from much higher density of reaction sites and larger surface area. ${ }^{4-6}$ These thin-film-processed cathodes require much thinner thickness to yield comparable or superior performances to that of powder-processed cathodes., ${ }^{2,5}$, Nevertheless, when these thin cathodes are applied, the aforementioned button cell testing configuration sometimes are not able to exactly assess the performance of the SOFC. For example, in a previous study by the authors, a significant underestimation of the cell performance by using a button cell test set-up due to the lateral conduction loss at the thin-filmprocessed cathode, and the impact of the optimization of the current collection configuration to minimize the loss were reported. ${ }^{2}$

In the present study, another factor, the difference of the area of the electrode and the current collector, which can induce misinterpretation of the cell performance of the SOFC employing a thin-film-processed cathode, is investigated. Since the 4-point measurement is employed for the button cell tests (Fig. 1), if the current from the electrode/electrolyte interface can be collected without a significant loss, the area discrepancy may not cause major problems in considering the electrode area as the active area. This may be true for thick powder-processed electrodes. Yet it can be invalid for thin-film-processed electrodes which are very thin and prone to the lateral conduction loss. To probe the possibility, two anode-supported SOFCs with different thin-film-processed cathode areas $(1 \mathrm{~cm}$ by $1 \mathrm{~cm}$ and $1.5 \mathrm{~cm}$ by $1.5 \mathrm{~cm}$ ) are fabricated and the cell performance is measured in the same set-up (current collection area $1 \mathrm{~cm}$ by $1 \mathrm{~cm}$ ). The current-voltage-power (I-V-P) and electrochemical 


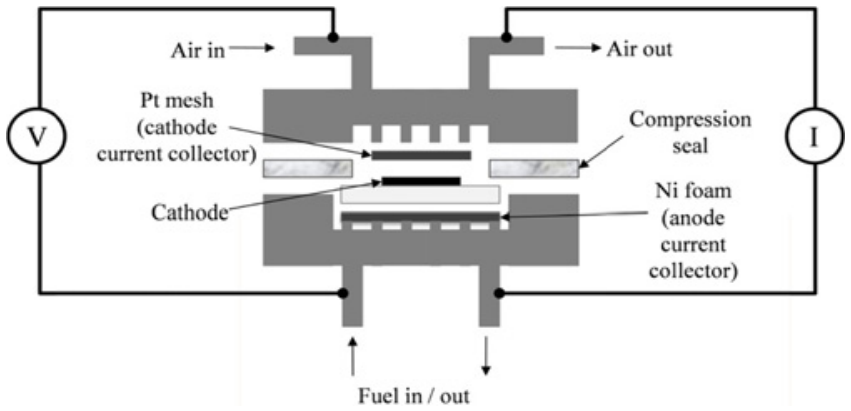

Fig. 1 A schematic of a button cell test set-up showing 4 point test configuration

impedance spectra (EIS) characteristics are compared and discussed.

\section{Experimental Details}

Two $2 \mathrm{~cm}$ by $2 \mathrm{~cm}$ NiO-yttria stabilized zirconia $\left(\mathrm{Zr}_{0.84} \mathrm{Y}_{0.16} \mathrm{O}_{2-\mathrm{d}}\right.$, YSZ) anode-supported cells with $\sim 6 \mu$ m-thick YSZ electrolyte were cut from a $10 \mathrm{~cm}$ by $10 \mathrm{~cm}$ anode-supported cell. A $200 \mathrm{~nm}$-thick gadolinia-doped ceria $\left(\mathrm{Ce}_{0.9} \mathrm{Gd}_{0.1} \mathrm{O}_{2-\delta}\right.$, GDC) buffer layer was deposited over the YSZ electrolyte to prevent the chemical reaction with the electrolyte and the cathode. Pulsed laser deposition (PLD) was used for the thin film deposition technique. For PLD, a $\mathrm{KrF}$ excimer laser $(\lambda=248 \mathrm{~nm})$ was used as a laser source. The laser fluence at the target surface was approximately $3 \mathrm{~J} / \mathrm{cm}^{2}$, and the target to substrate distance was fixed at $5 \mathrm{~cm}$. The GDC layer was deposited at a deposition substrate temperature $\left(\mathrm{T}_{\mathrm{s}}\right)$ of $700^{\circ} \mathrm{C}$ and an ambient deposition pressures $\left(\mathrm{P}_{\mathrm{amb}}\right.$, oxygen) of $6.67 \mathrm{~Pa}$.

A gradient-structured thin-film (GSTF) cathode was deposited on the GDC layer. The GSTF cathode consisted of three layers. The first layer contacting GDC was a $1 \mu$ m-thick $\mathrm{La}_{0.6} \mathrm{Sr}_{0.4} \mathrm{CoO}_{3-\delta}$ (LSC)-GDC composite (LSC:GDC $=1: 1$ vol. ratio) layer deposited at $\mathrm{T}_{\mathrm{s}}=700^{\circ} \mathrm{C}$ and $\mathrm{P}_{\mathrm{amb}}=26.66 \mathrm{~Pa}$, the second layer was a $2 \mu \mathrm{m}$-thick LSC-GDC composite layer deposited at $\mathrm{T}_{\mathrm{s}}=700{ }^{\circ} \mathrm{C}$ and $\mathrm{P}_{\mathrm{amb}}=39.99 \mathrm{~Pa}$, and the third (top) layer was a $2 \mu \mathrm{m}$-thick single LSC layer deposited at room temperature and $\mathrm{P}_{\mathrm{amb}}=13.33 \mathrm{~Pa}$ then post-annealed at $650^{\circ} \mathrm{C} 1$ hour in air. The cathode area of one cell was $1 \mathrm{~cm}$ by $1 \mathrm{~cm}$ and that of the other cell was $1.5 \mathrm{~cm}$ by $1.5 \mathrm{~cm}$.

Both cells were subjected to the EIS and I-V-P measurements from 650 to $450^{\circ} \mathrm{C}$ at intervals of $50{ }^{\circ} \mathrm{C}$, in the button cell test set-up shown in Fig. 1. Air and humidified $\mathrm{H}_{2}\left(3 \% \mathrm{H}_{2} \mathrm{O}\right)$ were used as the oxidant and the fuel, respectively, and the flow rates of each side were kept at $200 \mathrm{sccm}$. The electrochemical characterization was performed by using an Iviumstat analyzer. The cell test configuration and method were reported in detail in a previous work by authors. ${ }^{8}$ The whole topview image and the cross-sectional microstructure of the tested cell were taken by using a digital camera and a scanning electron microscope (SEM), respectively.

\section{Results and Discussion}

In Fig. 2, digital pictures of the tested cell are displayed. Fig. 2(a) is the top-view of the cell with a $1 \mathrm{~cm}$ by $1 \mathrm{~cm}$ cathode (will be denoted
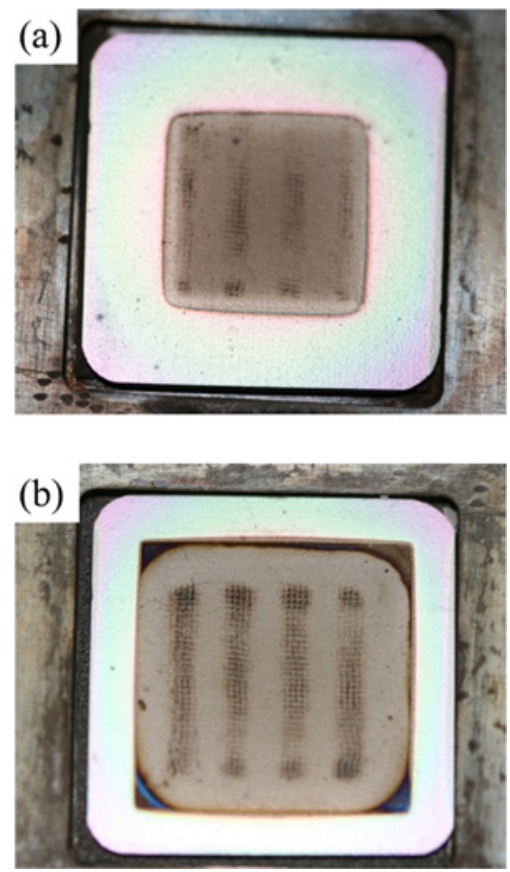

Fig. 2 Digital photographs of the top-views of (a) Cell-1.0 and (b) Cell-2.25

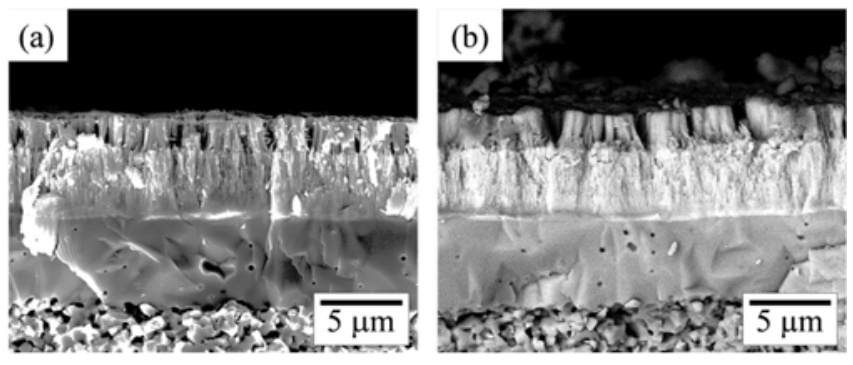

Fig. 3 Cross-sectional microstructures of (a) Cell-1.0 and (b) Cell-2.25

as the Cell-1.0, the number represents the cathode are in $\left.\mathrm{cm}^{2}\right)$, and Fig. 2(b) is that of the cell with a $1.5 \mathrm{~cm}$ by $1.5 \mathrm{~cm}$ cathode (will be denoted as Cell-2.25). The cathode areas were fabricated as intended and the remaining mesh marks at the surface of the cathodes indicate that the physical contact between the current connector and the cathode was appropriate. In Fig. 3, cross-sectional microstructures of each cell are presented. Fig. 3(a) is from the Cell-1.0 and Fig. 3(b) is from the Cell2.25. It is confirmed that the vertical dimensions of the electrolyte, buffer and cathode are almost identical, so it is clear that these cells are only different in terms of the cathode area.

In Fig. 4, the I-V-P curves of the Cell-1.0 (Fig. 4(a)) and those of the Cell-2.25 (Fig. 4(b)) are shown. Compared with the cell performances measured in the same cell test set-up reported in previous studies, ${ }^{5,8}$ the cell performance of the Cell-1.0 is in a reasonable range when the cathode type and thickness are taken into account. As can be seen in Fig. 4(b), the increment of the total power output of the Cell2.25 is substantial. For all tested temperatures, the Cell-2.25 produced much high power output than the Cell-1.0. In Table 1, the power output values at $0.7 \mathrm{~V}$ of each cell at each temperature, and the ratio of the power output values of the Cell-2.25 to that of the Cell-1.0 are listed.

For checking if there is any different electrode reaction mechanism between the two cells, EIS of the cells are compared. EIS measured at 
(a)

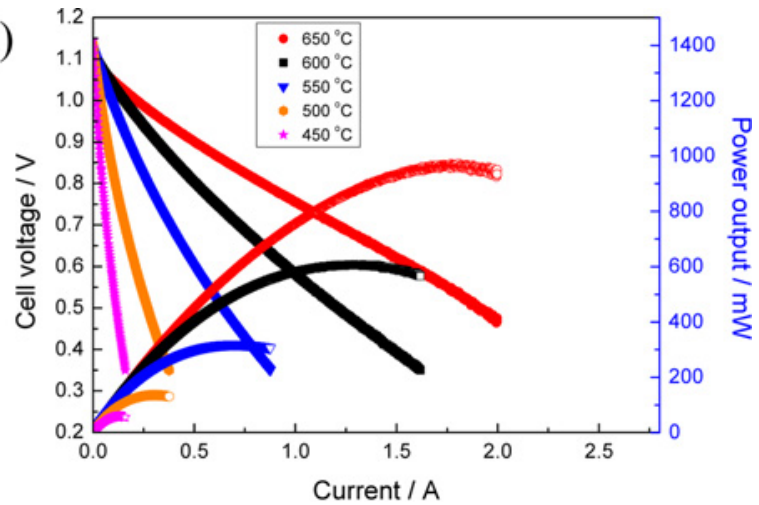

(b)

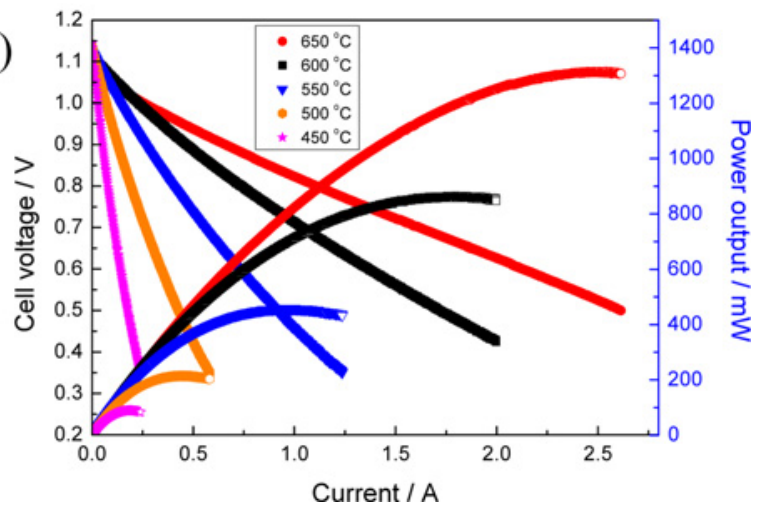

Fig. 4 I-V-P curves (a) Cell-1.0 and (b) Cell-2.25 measured at 650 $450^{\circ} \mathrm{C}$

Table 1 Power output values at $0.7 \mathrm{~V}$ of two cells measured at each temperature, and ratios of Power (Cell-2.25) to Power (Cell-1.0)

\begin{tabular}{cccc}
\hline & $\begin{array}{c}\text { Cell-1.0 } \\
\text { Power output at } \\
0.7 \mathrm{~V} \\
(\mathrm{~mW})\end{array}$ & $\begin{array}{c}\text { Cell-2.25 } \\
\text { Power output at } \\
0.7 \mathrm{~V} \\
(\mathrm{~mW})\end{array}$ & $\begin{array}{c}\text { Power } \\
(\text { Cell-2.25) to } \\
\text { Pemper (Cell-1.0) }\end{array}$ \\
\hline 650 & 840 & 1134 & 1.35 \\
\hline 600 & 504 & 728 & 1.44 \\
\hline 550 & 263 & 390 & 1.48 \\
\hline 500 & 109 & 183 & 1.68 \\
\hline 450 & 46 & 75 & 1.63 \\
\hline
\end{tabular}

all tested temperatures exhibited identical behavior and a representative data measured at $600^{\circ} \mathrm{C}$ are compared in Fig. 5. Fig. 5(a) is the comparison of the Nyquist plots of the both cells, and Fig. 5(b) is the comparison of the Bode plots of the both cells. It can be noticed from Fig. 5(a) that the overall shape of each Nyquist plot is almost the same. It is clearer that in the Bode plots in Fig. 5(b), there is no significant difference in the electrode reaction mechanism and only the absolute amount of the resistance of the Cell-2.25 is reduced compared with that of the Cell-1.0. Therefore, it can be concluded that the cathode area increment surely increase the overall power output, while the electrode reaction mechanism is identical.

Now, if the attention is turned to the last column of the Table 1, it is noticeable that the power output value ratio is not 2.25 which is the cathode area ratio of the Cell-2.25 to the Cell-1.0. This indicates that the current from the electrolyte/cathode interface is not entirely transferred to the current collector for the Cell-2.25 and a substantial loss is incurred. As was briefly mentioned in the introduction section, the loss can originate from the lateral conduction loss of the thin-film-processed

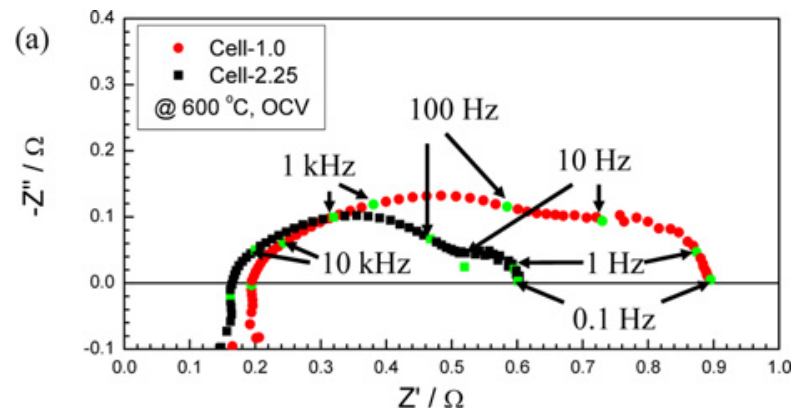

(b)

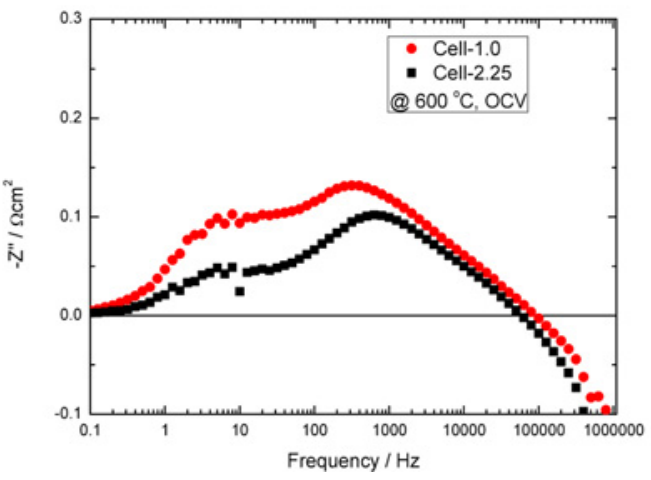

Fig. 5 (a) Nyquist plots and (b) Bode plots of the EIS data of Cell-1.0 and Cell-2.25 measured at $600{ }^{\circ} \mathrm{C}$

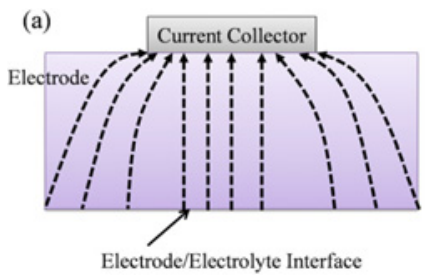

(b)

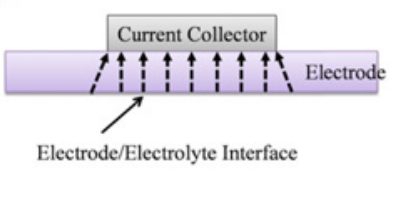

Fig. 6 Current flow from the interface to the current collector in (a) thick electrode and (b) thin electrode

cathode which can hinder the collection of the current flow from the outer cathode area that is not covered by the current collection area. The other possible major factor is the thin thickness of the cathode. If the cathode is thick, the current from the interface can reach the current collector which has the smaller area. However, for a thin cathode, there can be a certain limitation of the current contour for reaching the current collector. See Fig. 6 for the graphic explanation. Since thin-filmprocessed cathode has a thickness approximately $1 / 10$ of the powder processed cathode, the area discrepancy of the current collection and the cathode has a more significant impact. For the cases in which much thinner electrodes are implemented, such as micro-SOFCs, ${ }^{9-11}$ this problem can be more serious when the cell area is expanded.

Under these circumstances, there are two possibilities for misinterpretation of the cell performance. The cell performance of the Cell-1.0 can be considered as the 'true' cell performance of the SOFC cell measured at the present configuration with the consistency of the cathode and the current collection area. For the Cell-2.25, if the current collection area is counted as the active area, then substantial overestimation of the cell performance would occur. On the other hand, if the cathode area is considered as the active area, then significant underestimation of the cell performance would happen. Both cases are drawn in Fig. 7 using the cell performance measured at $600^{\circ} \mathrm{C}$. 


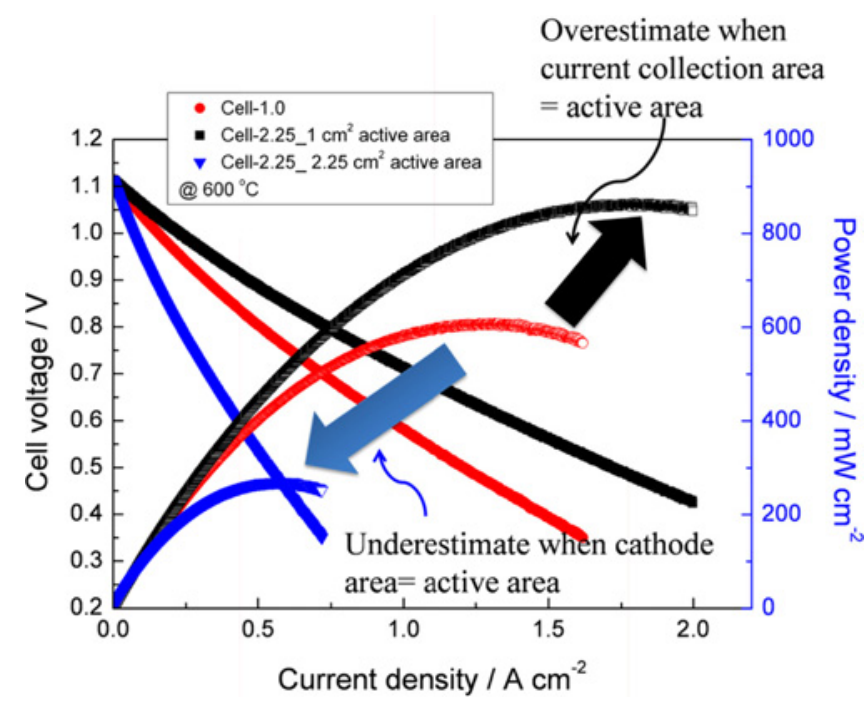

Fig. 7 Two possibilities of the misinterpretation of the cell performance when the current collection and cathode area discrepancy exists

Therefore, for precisely evaluating the SOFC performance when the thin-film-processed cathode is implemented, the consistency of the current collection area and the electrode area is important. Along with the suppression of the collection loss due to the impeded lateral conduction, ${ }^{2}$ another important consideration for using the thin-filmprocessed cathode is identified in the present study.

\section{Conclusions}

The influence of the area difference between the current collector and the thin-film-processed cathode is investigated. Two cells with different cathode area are fabricated and the unit cell performance is measured in a button cell test set-up. Significantly different cell power outputs are measured. The discrepancy is considered to originate from two major reasons: 1. limited lateral conduction and 2. thin thickness of the cathode. These characteristics are more specific for the thin-film-processed cathode. Either overestimation or underestimation of the cell performance is highly possible depending on which area is counted as the active area (overestimation when the smaller area is chosen, underestimation when the larger area is chosen between the current collection area and the cathode area). Thus, the consistency of the current collection area and the electrode area is essential for precisely evaluating the SOFC performance when the thin-film-processed cathode is implemented.

\section{ACKNOWLEDGEMENT}

This work was financially supported by the Young Fellow Program of KIST and the Global Frontier R\&D Program on Center for Multiscale Energy Systems (2011-0031579) funded by the National Research Foundation under the Ministry of Science, ICT \& Future Planning, Korea. The authors would appreciate Mr. Doo-Hwan Myung for his experimental assistance.

\section{REFERENCES}

1. Wachsman, E. D. and Lee, K. T., "Lowering the Temperature of Solid Oxide Fuel Cells,” Science, Vol. 334, No. 6058, pp. 935-939, 2011.

2. Noh, H.-S., Hwang, J., Yoon, K., Kim, B.-K., Lee, H.-W., et al., "Optimization of Current Collection to Reduce the Lateral Conduction Loss of Thin-Film-Processed Cathodes," Journal of Power Sources, Vol. 230, pp. 109-114, 2013.

3. Cui, D., Yang, C., Huang, K., and Chen, F., "Effects of Testing Configurations and Cell Geometries on the Performance of a SOFC: A Modeling Approach," International Journal of Hydrogen Energy, Vol. 35, No. 19, pp. 10495-10504, 2010.

4. Peters, C., Weber, A., and Ivers-Tiffee, E., "Nanoscaled $\left(\mathrm{La}_{0.5} \mathrm{Sr}_{0.5}\right) \mathrm{CoO}_{3-\delta}$ Thin Film Cathodes for SOFC Application at $500^{\circ} \mathrm{C}<\mathrm{T}<700^{\circ} \mathrm{C}$," Journal of the Electrochemical Society, Vol. 155, No. 7, pp. B730-B737, 2008.

5. Noh, H.-S., Lee, H., Ji, H.-I., Lee, H.-W., Lee, J.-H., and Son, J.-W., "Limitation of Thickness Increment of Lanthanum Strontium Cobaltite Cathode Fabricated by Pulsed Laser Deposition,” Journal of the Electrochemical Society, Vol. 158, No. 1, pp. B1-B4, 2011.

6. Lee, W. and Prinz, F. B., "Localized Charge Transfer Reactions near the Pt-YSZ Interfaces using Kelvin Probe Microscopy," Int. J. Precis. Eng. Manuf.-Green Tech., Vol. 1, No. 3, pp. 201-205, 2014.

7. Joos, J., Ender, M., Carraro, T., Weber, A., and Ivers-Tiffée, E., "Representative Volume Element Size for Accurate Solid Oxide Fuel Cell Cathode Reconstructions from Focused Ion Beam Tomography Data," Electrochimica Acta, Vol. 82, pp. 268-276, 2012.

8. Myung, D.-H., Hwang, J., Hong, J., Lee, H.-W., Kim, B.-K., et al., "Pulsed Laser Deposition of $\mathrm{La}_{0.6} \mathrm{Sr}_{0.4} \mathrm{CoO}_{3-\delta}-\mathrm{Ce}_{0.9} \mathrm{Gd}_{0.1} \mathrm{O}_{2-\delta}$ NanoComposite and Its Application to Gradient-Structured Thin-Film Cathode of SOFC," Journal of The Electrochemical Society, Vol. 158, No. 8, pp. B1000-B1006, 2011.

9. Huang, H., Nakamura, M., Su, P., Fasching, R., Saito, Y., and Prinz, F. B., "High-Performance Ultrathin Solid Oxide Fuel Cells for LowTemperature Operation," Journal of the Electrochemical Society, Vol. 154, No. 1, pp. B20-B24, 2007.

10. An, J., Kim, Y.-B., Park, J., Gur, T. M., and Prinz, F. B., "ThreeDimensional Nanostructured Bilayer Solid Oxide Fuel Cell with 1.3 $\mathrm{W} / \mathrm{cm}^{2}$ at $450^{\circ} \mathrm{C}$, Nano Letters, Vol. 13, No. 9, pp. 4551-4555, 2013.

11. An, J., Kim, Y. B., Jung, H. J., Park, J. S., Cha, S. W., et al., "Structural and Compositional Analysis of Solid Oxide Fuel Cell Electrolytes using Transmission Electron Microscopy,” Int. J. Precis. Eng. Manuf., Vol. 13, No. 7, pp. 1273-1279, 2012. 